\title{
Effect of lead on root growth
}

\section{Mouna Fahr 1,2,3, Laurent Laplaze ${ }^{3,4}$, Najib Bendaou ${ }^{1}$, Valerie Hocher ${ }^{3}$, Mohamed El Mzibri ${ }^{2}$, Didier Bogusz ${ }^{3}$ and Abdelaziz Smouni ${ }^{1}$ *}

${ }^{1}$ Laboratoire de Physiologie et Biotechnologie Végétale, Faculté des Sciences, Université Mohammed V-Agdal, Rabat, Morocco

2 Laboratoire de Biotechnologie des Plantes, Centre National de l'Energie, des Sciences et des Techniques Nucléaires, Unité de Biologie et Recherches Médicales- Division Sciences du Vivant, Rabat, Morocco

${ }^{3}$ Equipe Rhizogenèse, Institut de Recherche pour le Développement, Unité Mixte de Recherche Diversité Adaptation et Developpement des Plantes, Université Montpellier 2, Montpellier, France

${ }^{4}$ Laboratoire mixte international Adaptation des Plantes et microorganismes associés aux Stress Environnementaux, Laboratoire Commun de Microbiologie Institut de Recherche pour le Développement/Institut Sénégalais de Recherches Agricoles/Université Cheikh Anta Diop, Centre de Recherche de Bel Air, Dakar, Senegal

\section{Edited by:}

Douglas Godbold, Universität für Bodenkultur Wien, Austria

\section{Reviewed by:}

Cristina Nabais, University of Coimbra, Portugal

Rubén Retuerto, Universidade de

Santiago de Compostela, Spain

\section{${ }^{*}$ Correspondence:}

Abdelaziz Smouni, Laboratoire de Physiologie et Biotechnologie

Végétale, Faculté des Sciences, Université Mohammed V - Agdal, 4 Avenue Ibn Battouta, BP 1014, 10001 Rabat, Morocco

e-mail: azizsmouni@yahoo.com
Lead $(\mathrm{Pb})$ is one of the most widespread heavy metal contaminant in soils. It is highly toxic to living organisms. Pb has no biological function but can cause morphological, physiological, and biochemical dysfunctions in plants. Plants have developed a wide range of tolerance mechanisms that are activated in response to $\mathrm{Pb}$ exposure. $\mathrm{Pb}$ affects plants primarily through their root systems. Plant roots rapidly respond either (i) by the synthesis and deposition of callose, creating a barrier that stops $\mathrm{Pb}$ entering (ii) through the uptake of large amounts of $\mathrm{Pb}$ and its sequestration in the vacuole accompanied by changes in root growth and branching pattern or (iii) by its translocation to the aboveground parts of plant in the case of hyperaccumulators plants. Here we review the interactions of roots with the presence of $\mathrm{Pb}$ in the rhizosphere and the effect of $\mathrm{Pb}$ on the physiological and biochemical mechanisms of root development.

Keywords: root, lead, tolerance, uptake, root development

\section{INTRODUCTION}

Lead $(\mathrm{Pb})$ is a heavy metal of anthropogenic origin (Sharma and Dubey, 2005). $\mathrm{Pb}$ is a pollutant that accumulates in soils, sediments, and water and is extremely persistent in the environment (Traunfeld and Clement, 2001). Pb has no biological function and it is toxic to living organisms even at low concentrations. Although $\mathrm{Pb}$ is not an essential element, some plant species proliferate in $\mathrm{Pb}$ contaminated area and accumulate it in different parts. Roots are the first organ in contact with the various components of rhizosphere (Lynch and Whipps, 1990). Roots have evolved various mechanisms to reduce $\mathrm{Pb}$ uptake and transfer to the aboveground parts of the plant, and limit its deleterious effects. This article reviews the origins of $\mathrm{Pb}$ contamination, availability, and uptake of $\mathrm{Pb}$, and recent knowledge on physiological, biochemical, and ultrastructural changes in roots due to the presence of $\mathrm{Pb}$ in the rhizosphere.

\section{SOURCES OF LEAD}

Lead is one of the most widely distributed trace metals. It is ranked second of all hazardous substances by the Agency for Toxic Substances and Disease Registry (ATSDR, 2007). Because of natural deposits and increasing human activities, $\mathrm{Pb}$ has become ubiquitous in the soil and in the environment. Natural inputs include weathering and erosion of parent rocks that $\mathrm{Pb}$ to the transfer of large quantities of metals to water bodies and land (Gadd, 2010). Volcanic eruptions also contribute to natural inputs. For instance, the atmospheric emission from volcanoes was estimated at 540-6,000 tons for 1983 (Nriagu and Pacyna, 1988), and 1,00010,000 tons for 2001 (Richardson et al., 2001). Pb has been used by humans for centuries but anthropogenic activities related to this metal have increased significantly in recent decades. These activities include mining, smelting, fuel combustion, synthetic fertilizers, and various industrial processes: building construction, $\mathrm{Pb}$-acid batteries, bullets and shot, solder, pewter, and fusible alloys (Mukai et al., 2001). Human activities significantly influence the global cycles of $\mathrm{Pb}$. In 2004, 3,150,000 tons of $\mathrm{Pb}$ were extracted from the earth's crust and brought into circulation in society (USGS, 2006). In 1983, a total of 400,000-1,000,000 tons of mobilized $\mathrm{Pb}$ were disposed of with waste from metal extraction (Nriagu and Pacyna, 1988).

Lead is not biodegradable and is extremely persistent in both water and soil. $\mathrm{Pb}$ can be retained in the environment for 150-5000 years (Saxena et al., 1999). Most of $\mathrm{Pb}$ accumulates in the top 8 " of the soil where it has a very low mobility. Without remedial action, high soil $\mathrm{Pb}$ levels will never return to normal (Traunfeld and Clement, 2001). When Pb enters the soil matrix, it is very difficult to remove it. The capacity of soil to adsorb $\mathrm{Pb}$ increases with increasing $\mathrm{pH}$, cation exchange capacity, redox potential, organic carbon content, and chelates (phosphate) levels (United States Environmental Protection Agency, 1992).

The main part of the extracted $\mathrm{Pb}$ will not contribute to longrange environmental transport or be in a form that is readily bioavailable, but may later in the life cycle $\mathrm{Pb}$ to local impacts if not managed properly. 


\section{AVAILABILITY AND UPTAKE OF LEAD BY ROOTS}

The rhizosphere is where interactions take place between roots and soils constituents (Lynch and Whipps, 1990). When a root absorbs water or nutrients from soil, ions and molecules move toward this organ both by mass flow with soil water and by diffusion (Robinson, 1991). Pb may be present in different fractions in the soils. It was previously thought that $\mathrm{Pb}$ had low solubility and availability for plant uptake because it forms precipitates with phosphates, sulfates, and chemicals in the rhizosphere (Blaylock and Huang, 2000). These geo-chemical forms of $\mathrm{Pb}$ in soils affect its solubility, which directly influences its mobility. However, roots produce and excrete protons, exudates and several metabolites, which can modify the soil $\mathrm{pH}$ and thus interfere with the dissolution processes and formation of soluble metal-organic complexes (Leyval and Berthelin, 1991). Citric, fumaric, and uronic acids as well as many polysaccharides are able to form complexes and to chelate metal ions including $\mathrm{Pb}$ (Mench et al., 1987). Indeed, in Vicia faba and Typha angustifolia, $\mathrm{Pb}$ uptake by roots was shown to increase significantly in the first hour after adding organic ligands [ethylenediaminetetraacetic acid (EDTA), citric acid; Muhammad et al., 2009; Shahid et al., 2012]. However, Quartacci et al. (2006) reported that citric acid supplied to a metal contaminated soil did not cause any change in metal uptake in Brassica juncea.

Lead uptake is greatly affected by rhizospheric processes. Lin et al. (2004) explained the ability of Oryza sativa L. to absorb high levels of $\mathrm{Pb}$ from soil by a decrease in soil $\mathrm{pH}$ due to root exudates, solubilization of $\mathrm{Pb}$ by rhizosphere microorganisms and complexation of $\mathrm{Pb}$ with organic matter at the soil-root interface. These authors also found larger amounts of $\mathrm{NH}_{4} \mathrm{OAc}$ extractable $\mathrm{Pb}$ in the rhizosphere than in bulk soil, pointing to the involvement of root activities in changes in $\mathrm{Pb}$ availability (Lin et al., 2004).

Uptake of and tolerance to $\mathrm{Pb}$ depends on root system conditions. In sunflower, $\mathrm{Pb}$ accumulation and cell response was shown to differ between seedlings with a primary root system (PRS) and seedlings with adventitious root systems (ARS) only (in which the primary roots were cut off). The ARS was found to be more tolerant to $\mathrm{Pb}$ than the PRS in Helianthus annuus L. and Allium cepa (Michalak and Wierzbicka, 1998; Strubińska and Hanaka, 2011). This suggests that ARS have additional mechanisms that protect them against $\mathrm{Pb}$ penetration and $\mathrm{Pb}$ induced oxidative stress. However, these mechanisms are still unknown.

Rhizosphere organisms also affect the metals availability and speciation. In Lantana camara, $\mathrm{Pb}$ accumulation in roots increases in the presence of earthworms (Pontoscolex corethrurus; Jusselme et al., 2012). Similar trends were observed in the Thlaspi caerulescens rhizosphere of Pb-contaminated soil (Epelde et al., 2008). These authors found that microbial activity was stimulated by interaction between microorganisms and macroorganisms. The effect of earthworms on $\mathrm{Pb}$ uptake may be due to their impact on the distribution of soil microorganisms by providing suitable conditions for microbial growth (Brown, 1995) but the mechanisms involved are not clear.

Lead availability is also affected by the presence of other heavy metals. Orroñoa et al. (2012) reported that $\mathrm{Pb}$ availability was reduced when it was supplied with five heavy metals $(\mathrm{Cd}, \mathrm{Zn}$, $\mathrm{Cr}, \mathrm{Cu}$, and $\mathrm{Ni}$ ) that have an antagonist effect. These authors also reported that, when $\mathrm{Pb}$ was supplied alone or in ternary combination (with $\mathrm{Zn}$ and $\mathrm{Cu}$ ), its availability increased due to the antagonistic interaction between $\mathrm{Cu}$ and $\mathrm{Zn}$, which made $\mathrm{Pb}$ more available for plant uptake.

The uptake of $\mathrm{Pb}$ is based mainly on the plant species and the interaction between roots (structures and synthesized exudates) and the rhizosphere (biochemical properties). Indeed, several factors must be taken into account when developing strategies for phytoremediation of $\mathrm{Pb}$. Besides the organic and mineral composition of the soil and rhizopheric organisms and microorganisms, the ability of roots to modify the mobility and the bioavailability of $\mathrm{Pb}$ by changing rhizospheric conditions can significantly contributes to a successful phytoremediation program.

\section{ROOT DEFENSE AGAINST LEAD STRESS}

In response to $\mathrm{Pb}$ exposure, plants have developed a variety of tolerance mechanisms (Figure 1). Roots are the first organs, exposed to $\mathrm{Pb}$ ions (Piechalak et al., 2002). The first defense strategy is to stop the metal entering the root tissues by excluding it (Mishra et al., 2006). Roots rapidly respond to the presence of $\mathrm{Pb}$ by forming mechanical barrier. In some plants, there is synthesis and deposition of callose between the plasma membrane and the cell wall. This newly formed structure functions as a barrier against stress factors including metals (Bacic et al., 2009; Krzesłowska, 2011). Samardakiewicz et al. (2012) examined whether callose forms an efficient barrier against $\mathrm{Pb}$ penetration in the roots of Lemna minor $\mathrm{L}$. exposed to $15 \mu \mathrm{M}$ of $\mathrm{Pb}$ for $6 \mathrm{~h}$. This treatment resulted in the synthesis and deposition of callose in the newly formed cell wall in the protoderm in the center of the root tip. After callose deposition the $\mathrm{Pb}$ concentration was restricted in these superficial cells. Similar observations have been made in other species exposed to $\mathrm{Pb}$ including Arabidopsis thaliana (Lummerzheim et al., 1995) and Funaria hygrometrica (Krzeslowska et al., 2009). Pb-induced callose deposition has been detected in the rhizodermis and in the center of the stele of Pb-treated soybean Glycine max roots tips (Samardakiewicz et al., 1996). Under metal stress, the synthesized callose inhibits cell-to-cell transport.

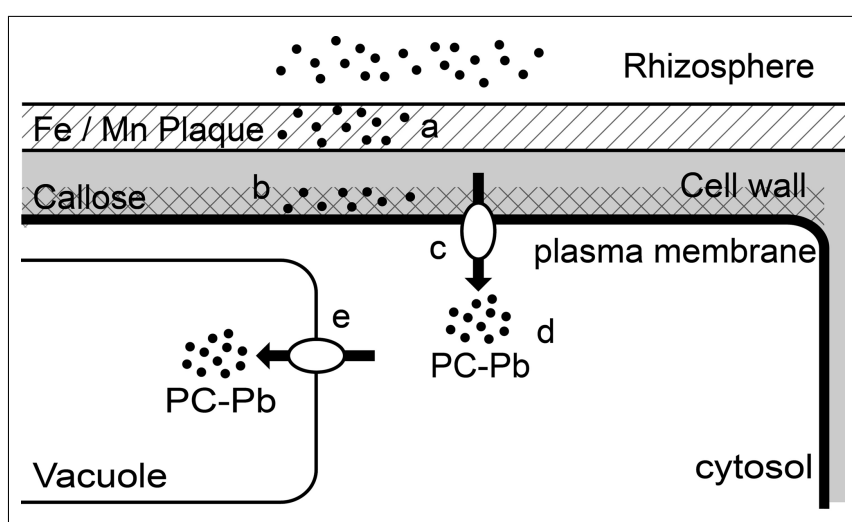

FIGURE 1 | Schematic representation of the types of root responses to lead toxicity in higher plants. (a) $\mathrm{Pb}$ sequestration in the Fe/Mn plaques; (b) $\mathrm{Pb}$ binding in callose formed in the new cell wall; (c) Pb fluxes across the plasma membrane; (d) Chelation of $\mathrm{Pb}$ in the cytosol by phytochelatin; (e) Transport of PC-Pb complex and sequestration in the vacuole. 
This may result in the prevention of a wide incursion of $\mathrm{Pb}$ ions, but it can simultaneously inhibit the transport of other molecules. However, the synthesis of callose is not a general pattern in plants in response to $\mathrm{Pb}$, in Zea mays and G. max, low level $\mathrm{Pb}$ treatment did not result in any callose deposition in root tissue. Although, these species synthesized callose in response to cadmium or arsenic (Pirselova etal., 2012). It seems that the formation of callose was closely related to the amount of $\mathrm{Pb}$ entering the cell, and subsequently the level of stress.

In some plants, the formation of Fe and Mn plaques on roots surface may provide a means of attenuation and external exclusion of metals. These plaques increase the sequestration of $\mathrm{Pb}$ on the root surface and in the rhizosphere, providing a means of external exclusion of soil $\mathrm{Pb}$ (Hansel et al., 2002). In some rice cultivars, Fe plaques were shown to affect patterns of $\mathrm{Pb}$ uptake and accumulation. Lower concentrations of $\mathrm{Pb}$ were found in the root tissues of rice plants with plaque compared to concentrations found in the plants without plaque. But the functions of plaque are limited as they are only efficient in relatively low or moderately $\mathrm{Pb}$-contaminated soil (Liu et al., 2011). Fe plaque and organic matrix with high $\mathrm{Pb}$ affinity were found in root epidermis of Typha latifolia, and were shown to prevent the accumulation and the translocation of $\mathrm{Pb}$ within the root (Qian et al., 2012; Feng et al., 2013).

In most plants, $90 \%$ of the total $\mathrm{Pb}$ is accumulated in roots (Kumar et al., 1995). Most $\mathrm{Pb}$ in roots is localized in the insoluble fraction of cell walls and nuclei, which is linked with the detoxification mechanism (Piechalak et al., 2002). After exposure to $\mathrm{Pb}$, cell mechanisms that minimize the potential for toxicity are rapidly activated. In the roots of several species including Pisum sativum (Malecka et al., 2009); Allium sativum (Jiang and Liu, 2010), and Athyrium yokoscense (Nishizono et al., 1987), the cell walls, the first barrier against $\mathrm{Pb}$ stress, can immobilize and accumulate some or even most $\mathrm{Pb}$ ions. The important role of the cell wall in the defense response of plants to trace metals was recently reviewed by Krzeslowska (2011). The capacity of cell walls to bind divalent metal cations mainly depends on the amount of polysaccharides with many carboxyl groups (Inoue et al., 2013). In Arabidopsis thaliana, $\mathrm{Pb}$-galacturonic acid fragments were detected in root treated with $\mathrm{Pb}$ (Polec-Pawlak et al., 2007). Brunet et al. (2008) showed that root of Lathyrus sativus $\mathrm{L}$. exposed to $\mathrm{Pb}$ contained much less calcium than control plants, and explained the reduction in $\mathrm{Ca}$ content by the replacement of $\mathrm{Ca}$ ions by $\mathrm{Pb}$ ions, which have a high affinity for pectin in cell walls. In Raphanus sativus, $\mathrm{Pb}^{2+}$ was also shown to bind to carboxyl groups of pectin in cell walls (Inoue et al., 2013). All the examples described above clearly show that the cell wall is one of the preferred and essential compartments for $\mathrm{Pb}$ accumulation, deposition, and sequestration. Therefore, these results shed a new light on the functioning of the cell walls in plant cell defense strategy against $\mathrm{Pb}$. Heavy metals including $\mathrm{Pb}$ are likely to enter plant cells via essentials cations transporters. AtCNGC, homologous to a non-selective cation channel, was suggested to enable $\mathrm{Pb}^{2+}$ entry since overexpression of the truncated gene resulted in tolerance to $\mathrm{Pb}^{2+}$ (Sunkar et al., 2000). $\mathrm{Ca}^{2+}$ was also reported to compete with $\mathrm{Pb}^{2+}$ for entry into rice root cells. When $\mathrm{Ca}^{2+}$ was supplied in the medium, it reduced $\mathrm{Pb}$ uptake and toxicity (Kim et al., 2002).
This suggests that $\mathrm{Pb}$ enters the root cells via $\mathrm{Ca}^{2+} / \mathrm{Mg}^{2+}$ gated channel (Kim et al., 2002).

In Allium sativum, as soon as excessive $\mathrm{Pb}$ ions enter the cytoplasm, a defense mechanism is activated, protecting the cells against $\mathrm{Pb}$ toxicity. Endocytotic and exocytotic processes are involved in these phenomena. The plasma membrane represents a "living" barrier of the cell to free inward diffusion of $\mathrm{Pb}$ ions. Invaginations of plasmalemma and some vesicles from dictyosomes and endoplasmic reticulum (ER) could prevent the free circulation of $\mathrm{Pb}$ ions in the cytoplasm. The vacuole is ultimately one of the main storage sites for metal sequestration (reviewed by Sharma and Dubey, 2005; Clemens, 2006). In Allium sativum roots, cysteine-rich peptides commonly referred as phytochelatins (PCs) were detected only after $2 \mathrm{~h}$ of $\mathrm{Pb}$ exposure (Jiang and Liu, 2010). This indicates that $\mathrm{Pb}$ ions can induce synthesis of PCs. Piechalak et al. (2002) demonstrated that the synthesis of PCs takes place under the influence of $\mathrm{Pb}$ ions in root cells of three tested plant species of the Fabaceae family: Pisum sativum, $V$. faba, and Phaseolus vulgaris. The complex $\mathrm{PC}-\mathrm{Pb}$ formed is then transported through the cytosol into the vacuoles (Piechalak et al., 2002). AtHMA3, encoding a $P_{1 \mathrm{~B}-2}$-ATPase, a heavy metal transporter, is localized in the vacuolar membrane of roots cells in Arabidopsis thaliana (Talke et al., 2006; Morel et al., 2009). This transporter is involved in the transfer of complexed heavy metals, including $\mathrm{Pb}$, from the cytoplasm to the vacuole (Morel et al., 2009). Root length was less affected by $\mathrm{Pb}$ in Arabidopsis thaliana plants overexpressing AtHMA3 than in wild-type plants (Morel et al., 2009). B. juncea appears to tolerate high concentrations of $\mathrm{Pb}$ thanks to its efficient cell roots vacuolar storage mechanisms. In this species, $\mathrm{Pb}$ sequestration was restricted to vacuoles (Meyers et al., 2008). In addition, it was suggested that exposure to $\mathrm{Pb}$ causes the production of additional vacuole specifically for $\mathrm{Pb}$ storage in the root tips of B. juncea (Meyers et al., 2008). The increase in the production of vacuoles could be regarded as a defense and adaptation strategy to elevated levels of $\mathrm{Pb}$ in the root cells. This roots potential storage can be used in phytoremediation processes. Table 1 shows a list of plant species effective in the accumulation of $\mathrm{Pb}$ in roots that could be used in rhizoremediation.

Table 1 | Plant species proposed for lead rhizoremediation.

\begin{tabular}{|c|c|c|}
\hline Plant species & Area of application & Reference \\
\hline Carex pendula & Wastewater & Yadav et al. (2011) \\
\hline Pistia stratiotes & Contaminated water & $\begin{array}{l}\text { Baharudin (2008); Vesely } \\
\text { etal. (2012) }\end{array}$ \\
\hline Eichhornia crassipes & Aquatic system & Tiwari et al. (2007) \\
\hline Scirpus americanus & Aquatic system & $\begin{array}{l}\text { Santos-Díaz and } \\
\text { Barrón-Cruz (2011) }\end{array}$ \\
\hline Phaseolus vulgaris & Contaminated water & Piechalak et al. (2002) \\
\hline Typha latifolia & Aquatic system & $\begin{array}{l}\text { Santos-Díaz and } \\
\text { Barrón-Cruz (2011) }\end{array}$ \\
\hline Cistus libanotis & Contaminated soil & Laplaze et al. (2010) \\
\hline Hirschfeldia incana & Contaminated soil & Auguy et al. (2013) \\
\hline
\end{tabular}


In a metallicolous ecotype of Elsholtzia argyi, $\mathrm{Pb}$ is found in fine particles dispersed through root cell membranes and cell wall fractions whereas in non-metallicolous roots, most $\mathrm{Pb}$ was found as large aggregates deposited in the cell wall fractions. These differences in localization explained why non-metallicolous roots were not able to transfer $\mathrm{Pb}$ to above ground parts via the apoplast (Islam et al., 2007). In some plants, $\mathrm{Pb}$ can be transported via vascular tissues to aerial parts (Hanc et al., 2009). In Sesbania drummondii, $\mathrm{Pb}$ is transported to leaves after complexation with acetate, nitrate, and sulfide (Sharma et al., 2004). In tobacco, a cyclic nucleotide gated channel (NtCBP4) was suggested to be involved in $\mathrm{Pb}$ transport (Sunkar et al., 2000).

To sum up, $\mathrm{Pb}$ pathway may include the following stages in roots: $\mathrm{Pb}$ can bound with physical barrier (callose, $\mathrm{Fe} / \mathrm{Mn}$ plaques, cell wall. ..). At high concentration, this barrier is broken and the flux of $\mathrm{Pb}$ enters the cell through the plasma membrane using the ions transporters. In cytoplasm, $\mathrm{Pb}$ is chelated with PCs. The complexe formed is then sequestered in the vacuoles. In accumulator plants, $\mathrm{Pb}$ can be transported via phloem to aerial parts (Figure 1).

Compared to $\mathrm{Zn}$ and $\mathrm{Cd}$, very little is known about the molecular mechanisms of acquisition, transport, and accumulation of $\mathrm{Pb}$. This is due first to the characteristics of $\mathrm{Pb}$ which precipitates with some components of the culture media making difficult to study its bioavailability to the roots. On the other hand, the lack of model plant for studying the mechanisms of tolerance to this metal. Among the 450 species known as metal hyperaccumulator and tolerant plants, $\mathrm{Pb}$ accumulating species are rather exceptional. Recently, Auguy et al. (2013) identified Hirschfeldia incana, a member of the Brassicaceae family, as a $\mathrm{Pb}$ accumulator plant. They demonstrated that this species, owing to its close genetic proximity to Arabidopsis, is a good model to identify genes involved in $\mathrm{Pb}$ tolerance and accumulation. This can open up new possibilities for understanding the molecular mechanisms of $\mathrm{Pb}$ tolerance in plants.

\section{EFFECT OF LEAD ON ROOT DEVELOPMENT AND PHYSIOLOGY PHYSIOLOGY AND ULTRASTRUCTURAL EFFECTS OF LEAD}

The primary effect of $\mathrm{Pb}$ toxicity in plants is a rapid inhibition of root growth, probably due to the inhibition of cell division in the root tip (Eun et al., 2000). It was demonstrated that $\mathrm{Pb}$ caused inhibition of cell division in Lemna minor roots (Samardakiewicz and Wozny, 2005). In several plant species, including Triticum aestivum (Dey et al., 2007; Kaur et al., 2013), Z. mays L. (Kozhevnikova et al., 2009), Pisum sativum (Malecka et al., 2009), and Sedum alfredii (Gupta etal., 2010), a decrease in the length and in root dry mass under $\mathrm{Pb}$ toxicity have been reported (Munzuroglu and Geckil, 2002). Verma and Dubey (2003) showed that growth of rice roots was significantly inhibited at $0.5-1 \mathrm{mM} \mathrm{Pb}^{2+}$; up to $40 \%$ reduction in root length was observed in 20-day-old rice seedlings. In Pb-treated Elsholtzia argyi and Elsholtzia splendens, the length and surface area of roots were strongly affected (Peng et al., 2005).

In response to $\mathrm{Pb}$ exposure, roots can also respond via changes in volume and diameter, with the production or inhibition of lateral roots. Root cells viability in rice is affected by $\mathrm{Pb}^{2+}$ ions and cell death increased at different $\mathrm{Pb}$ concentrations (Huang and Huang, 2008). Furthermore, cell wall distention, formation of folds, protuberances, and nicks were observed in response to different $\mathrm{Pb}$ concentrations in Triticum aestivum (Kaur et al., 2013), Elsholtzia argyi (Islam et al., 2007), and Allium cepa (Wierzbicka, 1998). Pb has been reported to disrupt microfibrils and microtubules, resulting in the formation of folds (Liu et al., 2009). In addition, Kaur et al. (2013) observed distentions and lesions in cell wall of Triticum aestivum roots as a result of activation of certain wall-degrading enzymes in response to $\mathrm{Pb}$ exposure. In $Z$. mays roots, $\mathrm{Pb}$ treatment resulted in $\mathrm{Pb}$ accumulation in the meristem in both apoplastic and symplastic pathways, associated with changes in microtubule organization (Eun et al., 2000).

Lead also has an impact on mineral homeostasis. Brunet et al. (2008) found that roots of Lathyrus sativus exposed to $\mathrm{Pb}$ showed an increase in $\mathrm{Pb}$ content along with an increase in $\mathrm{Na}$ levels, which is absorbed to compensate the loss in $\mathrm{K}$. A reduction in $\mathrm{Ca}$ contents in $\mathrm{Pb}$-exposed plants has also been observed in other species, such as maize, tomato, and mustard varieties (White and Broadley, 2003; Sharma and Dubey, 2005) and could result from the inhibition of $\mathrm{Ca}$ transporters by $\mathrm{Pb}$ ions (Wojas et al., 2007) and/or replacement of $\mathrm{Ca}$ ions with $\mathrm{Pb}$ ions due to its high affinity for $\mathrm{Ca}$ binding-sites on biological structures (Habermann et al., 1983). A reduction in $\mathrm{Zn}, \mathrm{Cu}$, and $\mathrm{K}$ contents in response to $\mathrm{Pb}$ exposure was observed in Cucumis sativus and $Z$. mays plants, as a result of a possible blockage of the transporter proteins by $\mathrm{Pb}$ (Sharma and Dubey, 2005).

Finally, $\mathrm{Pb}$ induces genotoxicity in plants (Rucińska et al., 2004). The comet assay evaluating the DNA-damaging effect of $\mathrm{Pb}$ showed an increase in DNA damage in root nuclei of tobacco and lupin (Rucińska et al., 2004; Gichner et al., 2008).

\section{BIOCHEMICAL EFFECTS OF LEAD}

The cytotoxic mechanisms of $\mathrm{Pb}$ in plants are not entirely understood. It has been reported that $\mathrm{Pb}$ leads to the overproduction of reactive oxygen species (ROS) such as superoxide radicals (radical $\left.\mathrm{O}^{2-}\right)$ and hydrogen peroxide $\left(\mathrm{H}_{2} \mathrm{O}_{2}\right)$ in plant cells (Reddy et al., 2005; Liu et al., 2010). These can cause lipid peroxidation, membrane damages, and oxidative stress (Sharma and Dietz, 2009). When pea (Pisum sativum) roots were exposed to 0.1 and $0.5 \mathrm{mM}$ of $\mathrm{Pb}\left(\mathrm{NO}_{3}\right)_{2}$, a rapid increase in superoxide anion $\left(\mathrm{O}_{2}^{-}\right)$and $\mathrm{H}_{2} \mathrm{O}_{2}$ levels occurs after 2 and $8 \mathrm{~h}$ of $\mathrm{Pb}$ treatment, respectively (Malecka et al., 2009). Liu et al. (2012) reported that after $\mathrm{Pb}$ treatment, roots of Ficus microcarpa produced high concentrations of $\mathrm{H}_{2} \mathrm{O}_{2}$ along with an increase in $\mathrm{O}_{2}^{-}$accumulation. $\mathrm{O}_{2}^{-}$is produced by nicotinamide adenine dinucleotide phosphate (NADPH) oxidase in the plasma membrane, and is converted to $\mathrm{H}_{2} \mathrm{O}_{2}$ through nonenzymatic pathways or by superoxide dismutase (SOD; Passardi et al., 2004). Some ROS can alter gene expression and modulate the activity of specific proteins in the plant defense system (Sharma and Dubey, 2005). To protect cells and tissues from injury and dysfunction, plants have developed various strategies, such as over expression of SOD, catalase (CAT), peroxidase (POX), and ascorbate POX genes. In addition, non-enzymatic antioxidants with low molecular weights, such as proline, cysteine, non-protein thiol, ascorbic acid, and glutathione, which can reduce oxidative stress by scavenging ROS are synthesized (Choudhury and Panda, 2005; Singh et al., 2006; Malecka et al., 2009). Responses to metal toxicity involving these enzymes and non-enzymatic 
antioxidants differ depending on the plant species, type of tissue, and metal concerned. Huang and Huang (2008) showed that in rice roots, $\mathrm{Pb}^{2+}$-induced ROS production and $\mathrm{Ca}^{2+}$ accumulation and activated MAP (mitogen-activated protein) kinases (proteins kinase cascade and major pathways by which extracellular stimuli are transduced into intracellular responses in all eukaryotic cells; Jonak et al., 2002) which are located in the apical region in rice roots. They demonstrated that treatment with glutathione, a powerful antioxidant, decreased $\mathrm{Pb}^{2+}$-induced root cells death and reduced MAP kinases activity. An increase in $\mathrm{H}_{2} \mathrm{O}_{2}$ content upon $\mathrm{Pb}$ exposure was observed in response to $\mathrm{Pb}^{2+}$, with an increase in CAT activity in Triticum aestivum (Kaur et al., 2013), Elsholtzia argyi (Islam et al., 2007), and Pisum sativum (Malecka et al., 2009). $\mathrm{Pb}$-induced lipid peroxidation and enhanced $\mathrm{H}_{2} \mathrm{O}_{2}$ content in roots of Allium sativum (Liu et al., 2009), Z. mays (Gupta et al., 2009), and B. campestris (Singh et al., 2011). However, Islam et al. (2007) and Kaur et al. (2013) reported a decline in the activity of POXs in Elsholtzia argyi and Triticum aestivum roots upon $\mathrm{Pb}$ exposure. Therefore, a higher concentration of $\mathrm{Pb}$ or longer treatment inhibit cell metabolism and $\mathrm{H}_{2} \mathrm{O}_{2}$ production, resulting in a decrease in the activity of some antioxidant enzymes (CAT; Verma and Dubey, 2003; Malecka et al., 2009). Plant enzymatic antioxidant defense systems vary with the plant species and with the intensity of $\mathrm{Pb}$ treatment. Production of ROS is common to different plant species. Some of these produced ROS may function as important signaling molecules by altering gene expression and modulating activity of specific defense proteins. However, all ROS can be very harmful to organisms at high concentrations.

Lead also increased protein and proline contents in roots of two varieties of $B$. napus with an increase in the concentration of $\mathrm{Pb}$ in the nutrient solution (Gohari et al., 2012). Proline plays an essential role in reducing environmental stress, including that caused by heavy metals. Piechalak et al. (2002) found that V. faba and

\section{REFERENCES}

ATSDR. (2007). Priority List of Hazardous Substances. Agency for Toxic Substances and Diseases Registry. Available at: http://www.atsdr.cdc.gov/ (accessed 28 July 2009).

Auguy, F., Fahr, M., Moulin, P., Brugel, A., Laplaze, L., El Mzibri, M., etal. (2013). Lead tolerance and accumulation in Hirschfeldia incana, a Mediterranean Brassicaceae from metalliferous mine spoils. PLoS ONE 8:e61932. doi: 10.1371/journal.pone.0061932.

Bacic, A., Fincher, G. B., and Stone, B. A. (2009). Chemistry, Biochemistry, and Biology of 1-3 Beta Glucans and Related Polysaccharides. San Diego, CA: Elsevier Science.

Baharudin, M. S. (2008). Lead and Cadmium Removal in Synthetic Wastewater Using Constructed Wetland. Pahang: Faculty of Chemical and Natural Resources Engineering, Universiti Malaysia Pahang.

Blaylock, M. J., and Huang, J. W. (2000). "Phytoextraction of metals," in Phytoremediation of Toxic Metals: Using Plants to Clean Up the Environment, eds I. Raskin and B. D. Ensley (New York: John Wiley \& Sons), 53-71.

Brown, G. (1995). How do earthworms affect microflora and faunal community diversity? Plant Soil 170 209-231. doi: 10.1007/BF02183068

Brunet, J., Repellin, A., Varrault, G., Terryn, N., and Zuily-Fodil, Y. (2008). Lead accumulation in the roots of grass pea (Lathyrus sativus L.): a novel plant for phytoremediation systems? C. R. Biol. 331, 859-864. doi: 10.1016/j.crvi.2008.07.002

Choudhury, S., and Panda, S. K. (2005). Toxic effects, oxidative stress and ultrastructural changes in moss Taxithelium nepalense (Schwaegr.) Broth. under chromium and lead phytotoxicity. Water Air Soil Pollut. 167, 73-90. doi: 10.1007/s11270-005-8682-9

Clemens, S. (2006). Toxic metal accumulation, responses to exposure and mechanisms of tolerance in plants. Biochimie 88, 1707-1719. doi: 10.1016/j.biochi.2006.07.003

Pisum sativum roots produced high amount of thiol peptides and $\mathrm{PCs}$ after $\mathrm{Pb}$ exposure. Although, the high level of these proteins allows tolerance to $\mathrm{Pb}$ for these species roots.

\section{CONCLUSION}

Root system is the first organ in contact with the different components of the soil and water. By their exudates and their effects on rhizosphere activities (proliferation of microorganisms, metal chelation, acidification, etc.) plant roots can tolerate and in some cases accumulate high levels of $\mathrm{Pb}$. An overall higher rate of accumulation was observed in roots rather than leaves in several species. Almost $90 \%$ of $\mathrm{Pb}$ accumulated in a number of species of the Brassicaceae family (Kumar etal., 1995) and some crops species such as Z. mays (Małkowski et al., 2002) and Pistia stratiotes (Vesely et al., 2012) was located in roots. This accumulator potential can be used in phytoremediation process. Rhizofiltration is a subset technique that uses both terrestrial and aquatic plants roots to absorb, concentrate, and precipitate metals from polluted water to their biomass (Dushenkov et al., 1995). This technique is cost-effective, and can be used for site restoration including maintenance of the biological activities of the polluted site. In this context, several plants have been identified whose roots could be used to clean up land contaminated by $\mathrm{Pb}$. Therefore, improvement of the capacity of plant roots to tolerate and accumulate $\mathrm{Pb}$ by genetic engineering should open up new opportunities for rhizoremediation.

\section{ACKNOWLEDGMENTS}

Abdelaziz Smouni and Mouna Fahr are indebted to IRD for visiting scientist and Ph.D. fellowships. We are thankful to the Laboratoire Mixte International (LMI), Biotechnologie Microbienne et Végétale (IRD/Mohammed V University, Rabat) for financial support.

Dey, S. K., Dey, J., Patra, S., and Pothal, D. (2007). Changes in the antioxidative enzyme activities and lipid peroxidation in wheat seedlings exposed to cadmium and lead stress. Braz. J. Plant Physiol. 19, 53-60 doi: 10.1590/S1677-04202007000100 006

Dushenkov, V., Kumar, P. B. N., Motto, H., and Raskin, I. (1995). Rhizofiltration: the use of plants to remove heavy metals from aqueous streams. Environ. Sci. Technol. 29, 1239-1245. doi: 10.1021/es00005a015

Epelde, L., Hernandez-Allica, J., Becerril, J. M., Blanco, F., and Garbisu, C. (2008). Effects of chelates on plants and soil microbial community: comparison of EDTA and EDDS for lead phytoextraction. Sci. Total Environ. 401, 21-28. doi: 10.1016/j.scitotenv.2008.03.024

Eun, S. O., Youn, H. S., and Lee, Y. (2000). Lead disturbs microtubule organization in the root meristem of Zea mays. Physiol. Plant. 110, 357-365. doi: 10.1034/j.13993054.2000.1100310.x
Feng, H., Qian, Y., Gallagher, F., Wu, M., Zhang, W., Yu, L., et al. (2013). Lead accumulation and association with Fe on Typha latifolia root from an urban brownfield site. Environ. Sci. Pollut. Res. Int. 20, 37433750. doi: 10.1007/s11356-0121298-x

Gadd, G. M. (2010). Metals, minerals and microbes: geomicrobiology and bioremediation. Microbiology 156, 609-643. doi: 10.1099/mic.0. 037143-0

Gichner, T., Žnidar, I., and Száková, J. (2008). Evaluation of DNA damage and mutagenicity induced by lead in tobacco plants. Mutat. Res. 652, 186-190.

Gohari, M., Habib-Zadeh, A. R., and Khayat, M. (2012). Assessing the intensity of tolerance to lead and its effect on amount of protein and proline in root and aerial parts of two varieties of rape seed (Brassica napus L.). J. Basic Appl. Sci. Res. 2, 935-938. Gupta, D. K., Huang, H. G., Yang, X. E., Razafindrabe, B. H. N., and Inouhe, M. (2010). The detoxification of 
lead in Sedum alfredii $\mathrm{H}$. is not related to but the glutathione. $J$. Hazard. Mater. 177, 437-444. doi: 10.1016/j.jhazmat.2009.12.052

Gupta, D. K., Nicoloso, F. T., Schetinger, M. R. C., Rossato, L. V., Pereira, L. B., Castro, G. Y., et al. (2009). Antioxidant defense mechanism in hydroponically grown Zea mays seedlings under moderate lead stress. J. Hazard. Mater. 172, 479-484. doi: 10.1016/j.jhazmat.2009.06.141

Habermann, E., Crowell, K., and Janicki, P. (1983). Lead and other metals can substitute for $\mathrm{Ca}^{2+}$ in calmodulin. Arch. Toxicol. 54, 61-70. doi: 10.1007/BF00277816

Hanc, A., Baralkiewicz, D., Piechalak, A., Tomaszewska, B., Wagner, B., and Bulska, E. (2009). An analysis of long-distance root to leaf transport of lead in Pisum sativum plants by laser ablation-ICP-MS. Int. J. Environ. Anal. Chem. 89, 651-659. doi: 10.1080/03067310802559366

Hansel, C. M., La Force, M. J., Fendorf, S., and Sutton, S. (2002). Spatial and temporal association of As and Fe species on aquatic plant roots. Environ. Sci. Technol. 36, 19881994.

Huang, T. L., and Huang, H. J. (2008). ROS and CDPK-like kinasemediated activation of MAP kinase in rice roots exposed to lead. Chemosphere 71, 1377-1385. doi: 10.1016/j.chemosphere.2007.11.031

Inoue, H., Fukuoka, D., Tatai, Y., Kamachi, H., Hayatsu, M., Ono, M., etal. (2013). Properties of lead deposits in cell walls of radish (Raphanus sativus) roots. J. Plant. Res. 126, 51-61. doi: 10.1007/s10265012-0494-6

Islam, E., Yang, X., Li, T., Liu, D., Jin, X., and Meng, F. (2007). Effect of $\mathrm{Pb}$ toxicity on root morphology, physiology and ultrastructure in the two ecotypes of Elsholtzia argyi. J. Hazard. Mater. 147, 806-816. doi: 10.1016/j.jhazmat.2007.01.117

Jiang, W., and Liu, D. (2010). Pbinduced cellular defense system in the root meristematic cells of Allium sativum L. BMC Plant Biol. 10:40. doi: 10.1186/1471-2229-10-40

Jonak, C., Ökrész, L., Bögre, L., and Hirt, H. (2002). Complexity, cross talk and integration of plant MAP kinase signalling. Curr. Opin. Plant Biol. 5, 415-424. doi: 10.1016/S13695266(02)00285-6

Jusselme, M. D., Poly, F., Miambi, E., Mora, P., Blouin, M., Pando, A., et al. (2012). Effect of earthworms on plant Lantana camara $\mathrm{Pb}$-uptake and on bacterial communities in root-adhering soil. Sci.
Total Environ. 416, 200-207. doi: 10.1016/j.scitotenv.2011.10.070

Kaur, G., Singh, H. P., Batish, D. R., and Kohli, R. K. (2013). Lead $(\mathrm{Pb})$-induced biochemical and ultrastructural changes in wheat (Triticum aestivum) roots. Protoplasma 1, 5362. doi: 10.1007/s00709-011-0372-4

Kim, Y. Y., Yang, Y. Y., and Lee, Y. (2002). $\mathrm{Pb}$ and $\mathrm{Cd}$ uptake in rice roots. Physiol. Plant. 116, 368-372. doi: 10.1034/j.1399-3054.2002.1160312.x Kozhevnikova, A. D., Seregin, I. V., Bystrova, E. I., Belyaeva, A. I., Kataeva, M. N., and Ivanov, V. B. (2009). The effects of lead, nickel, and strontium nitrates on cell division and elongation in maize roots. Russ. J. Plant Physiol. 56, 242-250. doi: 10.1134/S10214437090 20137

Krzesłowska, M. (2011). The cell wall in plant cell response to trace metals: polysaccharide remodeling and its role in defense strategy. Acta Physiol. Plant. 33, 3551. doi: $10.1007 /$ s11738-010-0581-z pp.35-51

Krzeslowska, M., Lenartowska, M., Mellerowicz, E., Samardakiewicz, S., and Wozny, A. (2009). Pectinous cell wall thickenings formation - a response of moss protonemata cells to lead. Environ. Exp. Bot. 65, 119-131. doi: 10.1016/j.envexpbot.2008.05.006

Kumar, P., Dushenkov, V., Motto, H., and Raskin, I. (1995). Phytoextraction: the use of plants to remove heavy metals from soils. Environ. Sci. Technol. 29, 1232-1238. doi: 10.1021/es00005a014

Laplaze, L., Doumas, P., Brhada, F., Ater, M., and Smouni, A. (2010). Use of Cistus libanotis to Clean Heavy Metals Containing Soils. PATENTSCOPE, International Application No. PCT/EP2010/056449.

Leyval, C., and Berthelin, J. (1991). Weathering of a mica by roots and rhizospheric microorganisms of pine. Soil Sci. Soc. Am. J. 55, 1009-1016. doi: 10.2136/ sssaj1991.03615995005500040020x

Lin, Q., Chen, Y. X., He, Y. F., and Tian, G. M. (2004). Root-induced changes of lead availability in the rhizosphere of Oryza sativa L. Agric. Ecosyst. Environ. 104, 605-613. doi: 10.1016/j.agee.2004.01.001

Liu, D., Xue, P., Meng, Q., Zou, J., Gu, J., and Jiang, W. (2009). $\mathrm{Pb} / \mathrm{Cu}$ effects on the organization of microtubule cytoskeleton in interphase and mitotic cells of Allium sativum L. Plant Cell Rep. 28, 695-702. doi: 10.1007/s00299-0090669-3
Liu, J., Leng, X., Wang, M., Zhu, Z., and Dai, Q. (2011). Iron plaque formation on roots of different rice cultivars and the relation with lead uptake. Ecotoxicol. Environ. Saf. 74, 1304-1309. doi: 10.1016/j.ecoenv.2011.01.017

Liu, N., Lin, Z., and Mo, H. (2012). Metal $(\mathrm{Pb}, \mathrm{Cd}$, and $\mathrm{Cu})$-induced reactive oxygen species accumulations in aerial root cells of the Chinese banyan (Ficus microcarpa). Ecotoxicology 21, 2004-2011. doi: 10.1007/s10646-012-0935-y

Liu, N., Lin, Z. F., Lin, G. Z., Song, L. Y., Chen, S. W., Mo, H., etal. (2010). Lead and cadmium induced alterations of cellular functions in leaves of Alocasia macrorrhiza L. Schott. Ecotoxicol. Environ. Saf. 73, 1238-1245. doi: 10.1016/j.ecoenv.2010.06.017

Lummerzheim, M., Sandroni, M., Castresana, C., Deoliveira, D., Vanmontagu, M., Roby, D., et al. (1995). Comparative microscopic and enzymatic characterization of the leaf necrosis induced in Arabidopsis thaliana by lead nitrate and by Xanthomonas campestris pv campestris after foliar spray. Plant Cell Environ. 18, 499-509. doi: 10.1111/j.1365 3040.1995.tb00550.x

Lynch, J. M., and Whipps, J. M. (1990). Substrate flow in the rhizosphere. Plant Soil 129, 1-10. doi: 10.1007/BF00011685

Malecka, A., Piechalak, A., and Tomaszewska, B. (2009). Reactive oxygen species production and antioxidative defense system in pea root tissues treated with lead ions: the whole roots level. Acta Physiol. Plant. 31, 1053-1063. doi: 10.1007/s11738009-0326-z

Małkowski, E., Kita, A., Galas, W., Karcz, W., and Kuperberg, J. M. (2002). Lead distribution in corn seedlings ( $\mathrm{Zea}$ mays L.) and its effect on growth and the concentrations of potassium and calcium. Plant Growth Regul. 37, 69-76.

Mench, M., Morel, J. L., and Guchert, A. (1987). Metal binding properties of high molecular weight soluble exudates from maize (Zea mays L.) roots. Biol. Fertil. Soils 3, 165-169. doi: 10.1007/BF00255778

Meyers, D. E. R., Auchterlonie, G. J., Webb, R. I., and Wood, B. (2008). Uptake and localisation of lead in the root system of Brassica juncea. Environ. Pollut. 153, 323-332. doi: 10.1016/j.envpol.2007.08.029

Michalak, E., and Wierzbicka, M. (1998). Differences in lead tolerance between Allium cepa plants developing from seeds and bulbs. Plant
Soil 199, 251-260. doi: 10.1023/ A: 1004321331708

Mishra, S., Srivastava, S., Tripathi, R. D., Kumar, R., Seth, C. S., and Gupta, D. K. (2006). Lead detoxification by coontail (Ceratophyllum demersum L.) involves induction of phytochelatins and antioxidant system in response to its accumulation. Chemosphere 65, 1027-1039. doi: $\quad 10.1016 /$ j.chemosphere.2006. 03.033

Morel, M., Crouzet, J., Gravot, A., Auroy, P., Leonhardt, N., Vavasseur, A., et al. (2009). AtHMA3, a P1B-ATPase allowing $\mathrm{Cd} / \mathrm{Zn} / \mathrm{Co} / \mathrm{Pb}$ vacuolar storage in Arabidopsis. Plant Physiol. 149, 894-904. doi: 10.1104/pp.108.130294

Muhammad, D., Chen, F., Zhao, J., Zhang, G., and Wu, F. (2009). Comparison of EDTA- and citric acidenhanced phytoextraction of heavy metals in artificially metal contaminated soil by Typha angustifolia. Int. J. Phytoremediation 11, 558-574. doi: 10.1080/15226510902717580

Mukai, H., Tanaka, A., Fujii, T., Zeng, Y., Hong, Y., Tang, J., et al. (2001). Regional characteristics of sulfur and lead isotope ratios in the atmosphere at several Chinese urban sites. Environ. Sci. Technol. 35, 1064-1071. doi: 10.1021/es001399u

Munzuroglu, O., and Geckil, H. (2002). Effects of metals on seed germination, root elongation, and coleoptile and hypocotyl growth in Triticum aestivum and Cucumis sativus. Arch. Environ. Contam. Toxicol. 43, 203-213. doi: 10.1007/s00244-002-1116-4

Nishizono, H., Suzuki, S., and Ishii, F. (1987). Accumulation of heavymetals in the metal tolerant fern, Athyrium yokoscense, growing on various environments. Plant Soil 102, 65-70. doi: 10.1007/BF02370902

Nriagu, J., and Pacyna, J. (1988). Quantitative assessment of worldwide contamination of air, water and soils by trace metals. Nature 333, 134-139. doi: $10.1038 / 333134 \mathrm{a} 0$

Orroñoa, D. I., Schindlera, V., and Lavadoab, R. S. (2012). Heavy metal availability in Pelargonium hortorum rhizosphere: interactions, uptake and plant accumulation. J. Plant Nutr. 35, 1374-1386. doi: 10.1080/01904167.2012.684129

Passardi, F., Penel, C., and Dunand, C. (2004). Performing the paradoxical: how plant peroxidases modify the cell wall. Trends Plant Sci. 9, 534-540. doi: 10.1016/j.tplants. 2004 . 09.002

Peng, H. Y., Tian, S. K., and Yang, X. E. (2005). Changes of root morphology and $\mathrm{Pb}$ uptake by two species 
of Elsholtzia under $\mathrm{Pb}$ toxicity. J. Zhejiang Univ. Sci. B 6, 546-552.

Piechalak, A., Tomaszewska, B., Baralkiewicz, D., and Malecka, A. (2002). Accumulation and detoxification of lead ions in legumes. Phytochemistry 60, 153-162. doi: 10.1016/S00319422(02)00067-5

Pirselova, B., Mistrikova, V., Libantova, J., Moravcikova, J., and Matusikova, I. (2012). Study on metal-triggered callose deposition in roots of maize and soybean. Biologia 67, 698-705. doi: 10.2478/s11756-012-0051-8

Polec-Pawlak, K., Ruzik, R., Lipiec, E., Ciurzynska, M., and Gawronska, $\mathrm{H}$ (2007). Investigation of $\mathrm{Pb}(\mathrm{II})$ binding to pectin in Arabidopsis thaliana. J. Anal. At. Spectrom. 22, 968-972. doi: 10.1039/b704157h

Qian, Y., Gallagher, F. J., Feng, H., and Wu, M. (2012). A geochemical study of toxic metal translocation in an urban brownfield wetland. Environ. Pollut. 166, 23-30. doi: 10.1016/j.envpol.2012.02.027

Quartacci, M. F., Argilla, A., Baker, A. J. M., and Navari-Izzo, F. (2006). Phytoextraction of metals from a multiply contaminated soil by Indian mustard. Chemosphere 63, 918-925. doi: 10.1016/j.chemosphere.2005.09.051

Reddy, A. M., Kumar, S. G., Jyothsnakumari, G., Thimmanaik, S., and Sudhakar, C. (2005). Lead induced changes in antioxidant metabolism of horsegram (Macrotyloma uniflorum (Lam.) Verdc.) and bengalgram (Cicer arietinum L.). Chemosphere 60, 97-104. doi: 10.1016/j.chemosphere.2004.11.092

Richardson, G. M., Garrett, R., Mitchell, I., Mah-Poulson, M., and Hackbarth, T. (2001). Critical Review on Natural Global and Regional Emissions of Six Trace Metals to the Atmosphere. International Lead Zinc Research Organisation, the International Copper Association, and the Nickel Producers Environmental Research Association.

Robinson, D. (1991). "Roots and resource fluxes in plants and communities," in Plant Root Growth. An Ecological Perspective (Special Publication of the British Ecological Society, No 10), ed. D. Atkinson (London: Blackwell Scientific), 103-130.

Rucińska, R., Sobkowiak, R., and Gwóźdź, E. A. (2004). Genotoxicity of lead in lupin root cells as evaluated by the comet assay. Cell. Mol. Biol. Lett. 9, 519-528.

Samardakiewicz, S., Krzesłowska, M., Bilski, H., Bartosiewicz, R., and Woźny, A. (2012). Is callose a barrier for lead ions entering Lemna minor $\mathrm{L}$. root cells? Protoplasma 249, 347-351. doi: 10.1007/s00709-011-0285-2

Samardakiewicz, S., Strawinski, P., and Wozny, A. (1996). The influence of lead on callose formation in roots of Lemna minor L. Biol. Plant. 38 463-467. doi: 10.1007/BF02896682

Samardakiewicz, S., and Wozny, A. (2005). Cell division in Lemna minor roots treated with lead. Aquat. Bot. 83, 289-295. doi: 10.1016/j.aquabot.2005.06.007

Santos-Díaz, M. S., and Barrón-Cruz, M. C. (2011). Lead, chromium and manganese removal by in vitro root cultures of two aquatic macrophytes species: Typha latifolia L. and Scirpus americanus Pers. Int. J. Phytoremediation 13, 538-551. doi: 10.1080/15226511003671379

Saxena, P. K., Krishnaraj, S., Dan, T., Perras, M. R., and Vettakkorumakankav, N. N. (1999). "Phytoremediation of heavy metal contaminated and polluted soils," in Heavy Metal Stress in Plants: From Molecules to Ecosystems, eds M. N. V. Prasa and J. Hagemeyer (New York: Springer), 305-329. doi: 10.1007/978-3-662-07745-0-14

Shahid, M., Pinelli, E., and Dumat, C. (2012). Review of $\mathrm{Pb}$ availability and toxicity to plants in relation with metal speciation; role of synthetic and natural organic ligands. $J$. Hazard. Mater. 219-220, 1-12. doi: 10.1016/j.jhazmat.2012.01.060

Sharma, N. C., Gardea-Torresdey, J. L., Parsons, J., and Sahi, S. V. (2004). Chemical speciation and cellular deposition of lead in Sesbania drummondii. Environ. Toxicol. Chem. 23, 2068-2073. doi: 10.1897/03-540

Sharma, P., and Dubey, R. (2005). Lead toxicity in plants. Braz. J. Plant Physiol. 17, 35-52. doi: 10.1590/S167704202005000100004

Sharma, S. S., and Dietz, K. J. (2009). The relationship between metal toxicity and cellular redox imbalance. Trends Plant Sci. 14, 43-50. doi: 10.1016/j.tplants.2008.10.007

Singh, H. P., Kaur, G., Batish, D. R., and Kohli, R. K. (2011). Lead (Pb)inhibited radicle emergence in Brassica campestris involves alterations in starch-metabolizing enzymes. Biol. Trace Elem. Res. 144, 1295-1301. doi: 10.1007/s12011-011-9129-3

Singh, S., Eapen, S., and D'souza, S. F. (2006). Cadmium accumulation and its influence on lipid peroxidation and antioxidative system in an aquatic plant, Bacopa monnieri L. Chemosphere 62, 233-246. doi: 10.1016/j.chemosphere.2005.05.017 Strubińska, J., and Hanaka, A. (2011). Adventitious root system reduces lead uptake and oxidative stress in sunflower seedlings. Biol. Plant. 55, 771-774.

Sunkar, R., Kaplan, B., Bouche, N., Arazi, T., Dolev, D., Talke, I. N., et al. (2000). Expression of a truncated tobacco NtCBP4 channel in transgenic plants and disruption of the homologous Arabidopsis CNGC1 gene confer $\mathrm{Pb} 2+$ tolerance. Plant J. 24, 533-542. doi: 10.1046/j.1365313x.2000.00901.x

Talke, I. N., Hanikenne, M., and Kramer, U. (2006). Zinc-dependent global transcriptional control, transcriptional deregulation, and higher gene copy number for genes in metal homeostasis of the hyperaccumulator Arabidopsis halleri. Plant Physiol. 142, 148-167. doi: 10.1104/pp.105.076232

Tiwari, S., Dixit, S., and Verma, N. (2007). An effective means of biofiltration of heavy metal contaminated water bodies using aquatic weed Eichhornia crassipes. Environ. Monit. Assess. 129, 253-256. doi: 10.1007/s10661-006-9358-7

Traunfeld, J. H., and Clement, D. L. (2001). Lead in Garden Soils. Home and Garden. College Park, MD: Maryland Cooperative Extension, University of Maryland.

United States Environmental Protection Agency. (1992). Selection of Control Technologies for Remediation of Lead Battery Recycling Sites. EPA/540/S-92/011. Washington, DC: Office of Emergency and Remedial Response, US Environmental Protection Agency.

USGS. (2006). Mineral Commodity Summaries. U.S. Geological Survey. Available at: http://minerals.usgs. gov/minerals/pubs/commodity/ lead/lead_mcs06.pdf

Verma, S., and Dubey, R. S. (2003). Lead toxicity induces lipid peroxidation and alters the activities of antioxidant enzymes in growing rice plants. Plant Sci. 164, 645-655. doi: 10.1016/S0168-9452(03)00022-0

Vesely, T., Neuberg, M., Trakal, L., Szakova, J., and Tlustoa, P. (2012). Water lettuce Pistia stratiotes L. response to lead toxicity. Water Air Soil Pollut. 223, 1847-1859. doi: 10.1007/s11270-011-0989-0

White, P. J., and Broadley, M. R. (2003). Calcium in plants. Ann. Bot. 92, 487-511. doi: 10.1093/aob/mcg164

Wierzbicka, M. (1998). Lead in the apoplast of Allium cepa L. root tips - ultrastructural studies. Plant Sci. 133, 105-119. doi: 10.1016/S01689452(98)00023-5

Wojas, S., Ruszczyńska, A., Bulska, E., Wojciechowski, M., and Antosiewicz, D. M. (2007). $\mathrm{Ca}^{2+}$-dependent plant response to $\mathrm{Pb} 2+$ is regulated by LCT1. Environ. Pollut. 147, 275-286.

Yadav, B. K., Siebel, M. A., and Van Bruggen, J. J. A. (2011). Rhizofiltration of a heavy metal (lead) containing wastewater using the wetland plant Carex pendula. CLEAN Soil Air Water 39, 467-474. doi: 10.1002/clen.201000385

Conflict of Interest Statement: The authors declare that the research was conducted in the absence of any commercial or financial relationships that could be construed as a potential conflict of interest.

Received: 26 February 2013; accepted: 16 May 2013; published online: 06 June 2013.

Citation: Fahr M, Laplaze L, Bendaou $N$, Hocher V, El Mzibri M, Bogusz D and Smouni A (2013) Effect of lead on root growth. Front. Plant Sci. 4:175. doi: 10.3389/fpls.2013.00175

This article was submitted to Frontiers in Functional Plant Ecology, a specialty of Frontiers in Plant Science.

Copyright (C) 2013 Fahr, Laplaze, Bendaou, Hocher, El Mzibri, Bogusz and Smouni. This is an open-access article distributed under the terms of the Creative Commons Attribution License, which permits use, distribution and reproduction in other forums, provided the original authors and source are credited and subject to any copyright notices concerning any third-party graphics etc. 